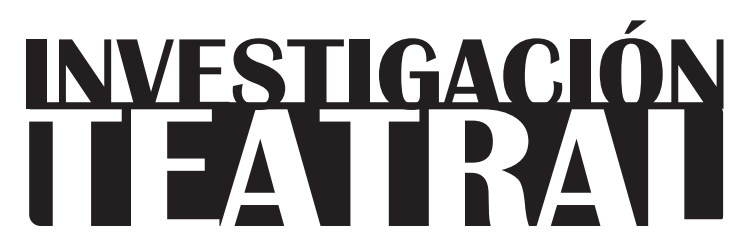

Revista de artes escénicas y performatividad

Vol. 9, Núm. 13

abril-septiembre 2018

Segunda época

ISSN impreso: 1665-8728

ISSN electrónico: 2594-0953

Universidad Veracruzana

\title{
Figuras del límite: Documentos, etnografía y teatro
}

\author{
Rodrigo Parrini*
}

\footnotetext{
* Departamento de Educación y Comunicación, Universidad Autónoma Metropolitana, Unidad Xochimilco, México.

e-mail:rodparrini@gmail.com
}

Recibido: 01 de septiembre de 2017

Aceptado: 29 de enero de 2018 
INVESTIGACIÓNTEATRAL

Revista de artes escénicas y performatividad

Vol. 9, Núm. 13

abril-septiembre 2018
Figuras del límite: Documentos,

etnografía y teatro

Rodrigo Parrini

\title{
Figuras del límite: Documentos, etnografía y teatro
}

\section{Resumen}

En este artículo reflexiono sobre las relaciones entre el teatro y la etnografía, a partir de un trabajo realizado con la agrupación Teatro Línea de Sombra entre migrantes centroamericanos, en la frontera sur de México. Mi interés no es describir etnográficamente lo acontecido, sino pensar el encuentro y entrecruzamiento de dos formas de documentación - la teatral y la etnográfica- y sus relaciones con un proceso poético de lectura y reconfiguración de una realidad que abordan en conjunto. Utilizo la noción de límite para trazar un eje de tensión entre las aproximaciones y miradas de ambas disciplinas.

Palabras clave: antropología, arte, documento, migración, frontera, México.

\section{Figures at the Limit: Documents, Ethnography and Theatre}

\begin{abstract}
In this article, I reflect on the relationship between theater and ethnography, with focus on a creative collaboration with the group Teatro Línea de Sombra (Shadow Line Theatre) and Central American migrants on the southern border of Mexico. The article aims to address the encounter and intertwining of two different forms of documentation - theatrical and ethnographic - and how they simultaneously relate with a poetic process that 'reads' a specific social reality. I use the concept of limit to create a tension between the approaches and perspectives of these two disciplines.
\end{abstract}

Keywords: anthropology, art, document, migration, border, Mexico. 


\section{Figuras del límite: Documentos, etnografía y teatro}

Toda literatura es un asalto al límite Franz Kafka

$\mathrm{E}$ n este artículo exploro algunos vínculos entre teatro y etnografía a partir de una experiencia con la agrupación Teatro Línea de Sombra (TLS). ${ }^{1}$ Este grupo montó Amarillo - una pieza dedicada a la migración que cruza la frontera norte de México para ingresar a los Estados Unidos de forma ilegal- en noviembre de 2013 en la ciudad de Tenosique, Tabasco. Dicha localidad se ha transformado en uno de los puntos más importantes de entrada de migrantes centroamericanos indocumentados a México y ahí se localiza el Hogar-Refugio para Migrantes "La 72", fundado por sacerdotes franciscanos en junio de 2011. ${ }^{2}$ Además de las dos funciones que dio de esa pieza, TLS realizó una serie de

1 Teatro Línea de Sombra es un proyecto cultural creado en 1993, conformado por creadores escénicos, pedagogos, investigadores y actores. En su página web, la agrupación define su trabajo como una "exploración en el quehacer contemporáneo del teatro y en los mecanismos de acercamiento e intercambio con otras y diversas experiencias de la creación escénica en el ámbito nacional e internacional", que privilegia "las zonas fronterizas de lo escénico" con otras disciplinas y la investigación "de los procesos de la escena y la creación, a partir de nuevas dramaturgias, procesos transdisciplinarios y la incorporación de relaciones nuevas con otros campos del conocimiento" (Teatro Línea de Sombra parr. 2).

${ }^{2}$ Fundado el 25 de abril de 2011 en la ciudad de Tenosique, este hogar es un proyecto de la Provincia Franciscana San Felipe de Jesús en el sureste de México. Su nombre recuerda la matanza de 72 migrantes -la 
actividades paralelas relacionadas con la migración que buscaban generar una aproximación sensible y crítica a este fenómeno por parte de los habitantes de la localidad.

En este texto no me interesa describir lo acontecido, sino en pensar el encuentro y entrecruzamiento de dos formas de documentación, la teatral y la etnográfica, y sus relaciones con un proceso poético de lectura y reconfiguración de una realidad que abordan en conjunto, pero también en paralelo. A partir de la colaboración con TLS, he seguido trabajando en una exploración etnográfica de los procesos de creación artística que alumbre los métodos antropológicos de investigación social. ${ }^{3}$

En las siguientes páginas me detendré a reflexionar, de modo ensayístico, sobre las estrategias de producción de la realidad que comprometen al teatro y a la etnografía, las formas de imaginación que ellas elaboran y las posibilidades que inaugura una lectura teatral de la migración, frente a otra etnográfica. Utilizo la noción de límite para trazar justamente un eje de tensión entre las aproximaciones y miradas del teatro y aquellas de la etnografía. Mi reflexión se centrará en identificar qué puede imaginar el teatro, en comparación con la antropología, frente a los mismos materiales. Despliego, por tanto, un ejercicio de imaginación etnográfica a partir de una impotencia asociativa que el teatro diluiría.

En un escrito sobre el neorrealismo italiano y el cine de Roberto Rossellini, Georges Didi-Huberman distingue los cuerpos documentados de los cuerpos líricos (ver Pueblos expuestos). Sostiene que podemos observar las escenas del cine de ese director italiano "desde la perspectiva rigurosa de los movimientos del trabajo" (169), que documentan con exactitud cómo sucede algo en la vida social (una redada policial o la pesca en un lago), y también desde "la óptica poética de los movimientos del pathos" (ibíd.), que introducen el amor y la muerte en esas escenas. Se trata de una poderosa distinción conceptual que, sin embargo, el autor no desarrolla cabalmente. En este artículo será retomada, pero desplazándola hacia las formas de generar interpretaciones e imágenes. Dado que trabajo con materiales que provienen tanto de la etnografía como del teatro, trazaré una distinción entre una aproximación documental, propia de la primera, y otra lírica, característica del segundo. Como se comprenderá, estos argumentos no son taxativos; se trata de reflexiones provisionales que permitirán desplegar una discusión.

Las figuraciones, escribe Donna Haraway, "son imágenes performativas que pueden ser habitadas. Las figuraciones, verbales o visuales, pueden ser mapas condensados de mundos

mayor parte centroamericanos - en la ciudad de San Fernando, Tamaulipas, en agosto de 2010, efectuada por células del crimen organizado en complicidad con la policía local. Este hogar es el primero que encuentran los migrantes que entran a México por la frontera entre Tabasco y Guatemala; les ofrece alojamiento, comida, atención jurídica, orientación y primeros auxilios.

${ }^{3}$ Ver Parrini, “Cuerpos figurantes..." y “Canto de palomas...”. Este último título se encuentra en prensa. 
discutibles" (28). Si las figuras que esbozaremos fueran mapas de mundos discutibles, condensarían de alguna manera el potencial disruptivo de tales mundos; es decir, los discutirían antes de que otras formas discursivas lo hicieran. La antropología se ha ocupado de figuras liminares o momentos de tránsito en que los sujetos pasaban ciertos umbrales para reingresar al orden social con un nuevo estatus (Turner 1991). Se trataba de figuras del límite, pasajeras y descriptibles. Las nuevas figuras del límite no surgen, a mi entender, de esas transiciones pautadas, sino de un desajuste generalizado de los espacios y las habitabilidades. Los umbrales rituales han sido reemplazados por umbrales biopolíticos donde las multitudes se agolpan sin poder salir. No hay tránsito y el umbral parece extenderse infinitamente. Un antropólogo sostiene que para los migrantes centroamericanos todo México es una frontera: una frontera vertical extensa (Fábregas Puig, "El concepto de frontera"). ¿Cómo comprender una frontera que se extiende como un territorio y que ya no es el límite sino la extensión misma? ¿Qué umbrales serían aquellos a los que se entra pero de los que aparentemente no se sale?

Los mapas de mundos discutibles que aquí están en juego, delinean el proceso migratorio en la frontera sur y - como dije antes - se produjeron en torno a ellos materiales líricos y documentales. Las figuras del límite que me interesa analizar son condensaciones singulares en esos mapas, localizadas en esos umbrales extensos y esas transiciones infinitas. Son, ante todo, nodos de una expulsión y no de una habitabilidad. ${ }^{4}$ La etnograf ía y el teatro dan cuenta de ellos de modos distintos. ${ }^{5}$

\section{Correspondencias y fronteras}

Trazar una línea tajante entre antropología y etnografía reedita viejas discusiones disciplinares y también sus horizontes futuros. Un modo clásico de distinguirlas ha sido atribuir a la etnografía el trabajo de campo y la descripción, y a la antropología la escritura y el análisis (Ingold 87). Si bien no es éste el lugar para reconstruir dicho punto de vista, parece que

${ }^{4}$ Saskia Sassen considera que la expulsión es una forma inédita, múltiple y compleja, mediante la cual poblaciones enteras son apartadas del desarrollo social y económico y dejadas a su suerte, que no puede ser explicada sólo por la desigualdad creciente que afecta a muchas sociedades contemporáneas. Sassen identifica algunas "lógicas de expulsión" que organizan un proceso de transformación social singular, en el que "la línea divisoria entre los que tienen acceso a los beneficios y los que no lo tienen se ha agudizado" y se ha hecho irreversible (11-12).

${ }^{5}$ La distinción que planteo entre teatro y etnografía puede resultar tajante y reductora. Entiendo que ambos campos son plurales y que no existe un teatro como tampoco una etnografía. Mantendré la distinción con fines analíticos y retóricos, sin perder de vista la diversidad que atraviesa a ambas disciplinas. 
diferenciar a una de otra es relevante para afincar los límites de la disciplina en su totalidad (Descola 66). A su vez, trazar una frontera clara entre el trabajo de campo y la escritura resulta igual de problemático. Al parecer, la antropología requiere una topología de sus actividades que no sólo las distinga, sino que también genere una cierta parsimonia en la que imaginamos que primero observamos y luego escribimos, o que el trabajo de campo (cualquiera que éste sea) sucede en un lugar distinto al de la escritura. También están en juego las temporalidades disciplinarias que permiten la organización de una investigación. Ingold argumenta que el trabajo de campo es una distinción imaginaria, una línea que se dibuja sobre la labor antropológica para diferenciar momentos y espacios.

Si la antropología no es etnografía, como sostiene el autor citado, esto se debe a que la primera es un diálogo incesante del antropólogo consigo mismo, con los otros y con el mundo que sucede mediante una correspondencia entre el antropólogo y sus interlocutores. ${ }^{6}$ No empieza al regresar del 'campo', porque éste no es más que un término que le permite al etnógrafo reunir e imaginar lo que ha dejado atrás cuando se encuentra abocado a describirlo en la escritura (88).

Laura Nader, por su parte, sostiene que la etnografía no sólo es una descripción, sino también una "teoría de la descripción" (211). Podríamos invertir el argumento de Ingold y pensar que la antropología es aquello que el etnógrafo imagina que hará cuando regrese de su trabajo de campo; entonces, la diferencia entre una y otra radicaría en sus desplazamientos y énfasis, antes que en las formas de conocimiento y los modos de escritura.

No obstante, pensar los límites me parece en este caso más un ejercicio antropológico que etnográfico, y corresponde al momento de inscribir un trabajo científico entre otras prácticas, por ejemplo, las artísticas. Si bien aquí me centro en la experiencia etnográfica que ocurrió a partir del encuentro con el lenguaje y el trabajo teatral y artístico, la lectura que propongo interroga las fronteras disciplinarias que comprometen la labor antropológica. Siguiendo a Ingold, la escritura de este texto traza un instante singular (que he llamado etnográfico) en el que sucedieron ciertos acontecimientos que tuvieron alguna forma de documentación. Si bien podría pensar que el artículo es una correspondencia, en el sentido polisémico del término, con otros interlocutores, también es una advertencia sobre los límites de dicho intercambio, dado que el lenguaje común que supone ese diálogo se ve perturbado por otros lenguajes que no son completamente traducibles.

La frontera entre teatro y etnografía sería el hiato en el que las correspondencias no llegan necesariamente a su destino o en que aquello que contienen, si las leyéramos, no resultaría cabalmente comprensible.

6 Así como el conocimiento etnográfico implica un intercambio intersubjetivo no replicable (Descola 69). 
INVESTIGACIÓNTEATRAL

Revista de artes escénicas y performatividad

Vol. 9, Núm. 13

abril-septiembre 2018
Figuras del límite: Documentos,

etnografía y teatro

Rodrigo Parrini

\section{Primer límite: la peste y los colgados}

A inicios de 2015 asistí, junto con algunos integrantes de Teatro Línea de Sombra, a una sesión de tarot; le pedí a una amiga tarotista que realizara una consulta colectiva grabada, a lo que ella accedió de manera excepcional. La pregunta era cómo encontrar un lenguaje para el proyecto que estábamos desarrollando y que se llamaba Carnaval de abandonados. ${ }^{7}$ Buscábamos encontrar, en el carnaval que cada año se realiza en Tenosique, un lenguaje y un espacio para discutir el abandono de los migrantes que transitaban por la localidad, política y performativamente. La noción de abandono se volvió central en mi trabajo etnográfico cuando desplacé mis preocupaciones de la sexualidad a la migración; fue un concepto que me permitió vincular las condiciones estructurales que organizaban la vida de las personas no heterosexuales, de las trabajadoras sexuales y de las personas que viven con VIH en la ciudad con las experiencias de los migrantes centroamericanos.

Propuse al tarot como un camino que nos acercara ese mundo a través de imágenes y metáforas. Alejandro Jodorowsky define al tarot como "un organismo de imágenes y formas [...], uno de los primeros lenguajes ópticos de la humanidad [que] responde a unas reglas de óptica proyectiva" (Psicomagia 125).

La carta que abrió la lectura fue El colgado, el doceavo arcano mayor del Tarot de Marsella. El colgado representaba el arcano mayor de los abandonados, que era el colectivo que orientaba la sesión. Jodorowsky propone pensar esta figura como "una inversión de la mirada y de sus perspectivas" (La vía del Tarot 220). Los abandonados, escribe Giorgio Agamben, están expuestos en un umbral donde vida y derecho, exterior e interior, se confunden (ver Homo sacer I). Están bajo un bando que los conmina y también los vulnera; han quedado a merced del poder, pero también entregados a su propia voluntad. En ellos, viejas figuras del derecho convergen con formas inéditas de desamparo o violencia.

En la lectura de tarot, los abandonados aparecían fragmentados por un orden social alienante, separados de sus propias emociones:

Y ahí están señalados por los militares, por el gobierno, están señalados si entran o no a un camión, si los bajan o suben. Es una batalla constante, la guerra, la revolución. Ellos viven todos los días con una revolución para poder obtener algo. No se les da tan fácil la vida. ${ }^{8}$

\footnotetext{
7 El proyecto culminó en febrero de 2016, cuando varias decenas de migrantes, muchos alojados en "La 72", y otros residentes en Tenosique, participaron en la comparsa migrante que ha desfilado en el carnaval. En otro texto analizo con detalle este acontecimiento (Parrini, "Cuerpos figurantes...").

${ }^{8}$ Lectura de tarot, 14 de marzo de 2015.
} 
INVESTIGACIÓNTEATRAL

Revista de artes escénicas y performatividad

Vol. 9, Núm. 13

abril-septiembre 2018
Figuras del límite: Documentos, etnografía y teatro

Rodrigo Parrini

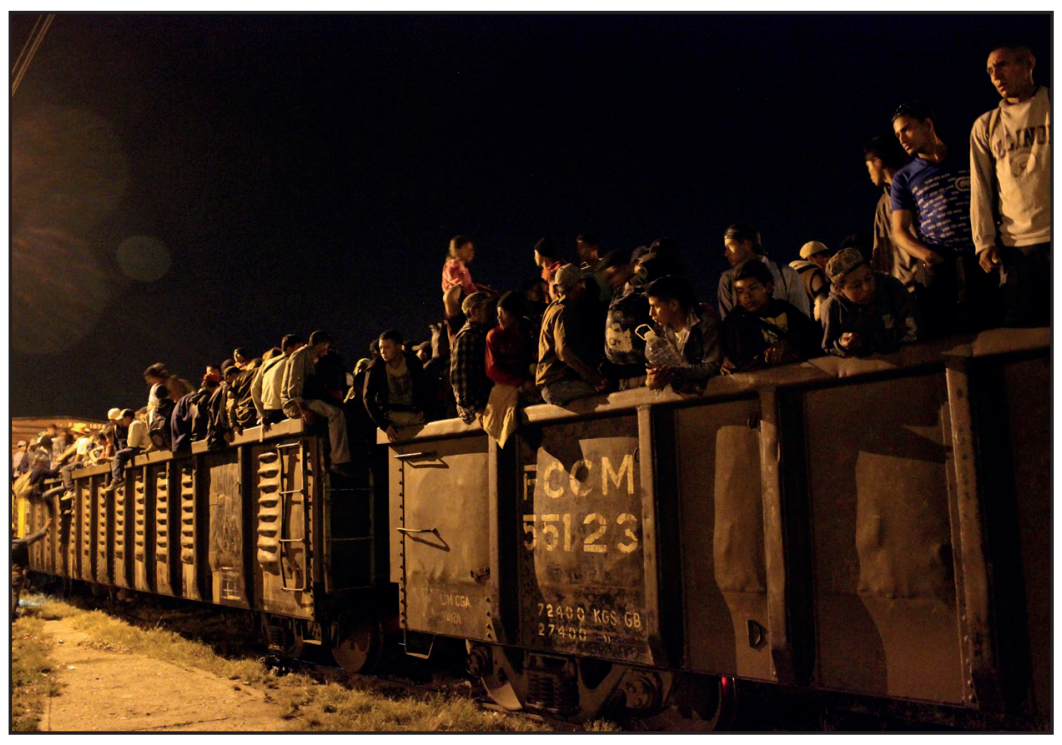

Vía Crucis Migrante. Tenosique, México, 2014. Fotografía de Marina España

El colgado es, literalmente, un migrante que viaja en tren, asido de alguna de sus partes para no caer. Pero también es el cadáver anónimo que queda expuesto en algún lugar público. Leeré el abandono a través de la peste.

En septiembre de 2014 encontraron en alguna carretera de Tenosique el cadáver de un migrante cuyo cuerpo "había explotado", según relataron algunos testigos. Los rumores advertían que había fallecido "por ébola", aunque los médicos diagnosticaron un sobrecalentamiento, producto de las altas temperaturas de la zona. Pronto se difundió el rumor de que "el ébola había llegado a Tenosique" en el cuerpo de ese migrante; era septiembre de 2014 y los medios de comunicación divulgaban abundante información sobre ese virus. Si el migrante no murió por ébola, no había de qué preocuparse: había sido el calor lo que "reventó" su cuerpo.

¿Podrían las epidemias constituir una ruta para producir teatro en la frontera, en torno al paso de los migrantes por Tenosique? ¿No son las epidemias fenómenos colectivos y corporales? ¿No son tránsitos, flujos infectos, trayectorias de la muerte, huellas de los cuerpos enfermos, de los rostros desencajados? Cuando el ébola estuvo cerca de Tenosique lo trajo un rumor, una palabra incierta, que se sustentaba en el cadáver de un migrante encontrado en la carretera, "reventado" según los médicos. Epidemia de las habladurías que se esparcieron por la ciudad, enfermedades del África repetidas miles de veces en los medios de comunicación, cuerpos que revientan y sangran. El calor de la zona no podía explicar esos eventos, tan parecidos a los que describía la televisión. Pestes mediáticas que buscan evidencias en cadáveres anónimos tirados en una carretera fronteriza. ¿No hay es- 
pectáculo en el rumor, en esa crueldad chismosa y una preocupación vaga? ¿Cómo llegan esas enfermedades 'africanas' a Tenosique? ¿Por qué las traerían los migrantes, como si tuvieran que viajar en otros cuerpos para encontrar a los ciudadanos sedentarios, temerosos e inquietos? ¿Por qué viene de fuera lo que amenaza a ese adentro aparente que sería una comunidad o una sociedad local?

Antonin Artaud, en su famosa relación entre peste y teatro, escribe:

[...] así como las imágenes de la peste, en relación con un potente estado de desorganización física, son como las últimas andanadas de una fuerza espiritual que se agota, las imágenes de la poesía en el teatro son una fuerza espiritual que inicia su trayectoria en lo sensible y prescinde de la realidad (El teatro 28).

Imágenes de la peste: un cuerpo que ha explotado pero se desconoce la causa, una desorganización física mortal; un cuerpo deshecho, sus órganos colapsados y rastros de sangre en su superficie. ¿Qué inicia ante esa imagen?, ¿qué "fuerzas espirituales” se agotaron en ese cadáver?, ¿podría empezar una poesía que comience su trayectoria en lo sensible y prescinda de la realidad?, ¿significaría prescindir del cadáver en este caso?, ¿qué sería lo sensible y qué lo real?

La etnografía llegaría a reconstruir los hechos, a escuchar las versiones, a seguir el rumor, a conversar con los médicos, a revisar los archivos y las imágenes. Iniciaría, tal vez, su trayectoria en lo sensible (el cadáver) para conocer lo real (la muerte). ¿Qué haría el teatro? Empezaría en el cadáver (lo sensible), pero podría prescindir de la realidad (la muerte); rodearía al cuerpo de otras poéticas que no fueran las médicas o las forenses, las mediáticas o las políticas. El teatro podría generar otra peste mediante rumores, suscitar otras imágenes, desplazar los cuerpos y regresar al cadáver (que no termina de significar, que se descompone pero que nunca deja de existir al estar rodeado lo irresuelto; es el único testigo de esos parajes africanos donde la gente muere de ébola delante de las cámaras de televisión).

Supongamos que el migrante ha muerto de ébola y que la enfermedad ha llegado desde muy lejos en el cuerpo de un nómada; ¿podría el teatro dotar de "fuerza espiritual" a esta llegada de lo lejano y distante, envolver el temor de imágenes y de otros rumores, sacralizar el cadáver como un vestigio de los extensos viajes de los virus y la pequeñez del mundo? La etnografía termina donde empieza el arte. El ébola es un rumor falso para el etnógrafo; para el dramaturgo/actor es el inicio de lo sensible, el sostén de la imaginación. Enfermedades lejanas, cadáveres expuestos, rumores temerosos, medicina y burocracias, necropsias. Nada ha terminado ahí, aunque el cadáver haya desaparecido en una fosa común. Las habladurías aún lo blanden; en algún sentido, lo velan. África esparcida en virus, otros mundos trans- 
formados en rumores y desmentidos. Duelos por cadáveres desconocidos, pero también por las efímeras protecciones de la lejanía; lo insospechado arriba a este lugar; los terrores globales se transforman en rumores locales. Los cuerpos expuestos son como peregrinos de todas las enfermedades, de todos los males, de los horrores que deseamos evitar pero que tememos. El cadáver del migrante es testigo de que todo está muy cerca.

Artaud dice que "si admitimos esta imagen espiritual de la peste, descubriremos en los humores del apestado el aspecto material de un desorden que, en otros planos, equivale a los conflictos, a las luchas, a los cataclismos y a los desastres que encontramos en la vida" (El teatro 29). Si el teatro puede descargar sobre el espectador las fuerzas de ese desorden como una epidemia — siguiendo a Artaud—, ¿debería renunciar al cadáver y quedarse con los rumores?, ¿exaltar las enfermedades?, ¿desbaratar la versión de los médicos y reafirmar ese texto anónimo que anuncia la llegada de la peste (el ébola) a las puertas de la ciudad? A diferencia del etnógrafo que trabaja con la veracidad de los hechos y no puede hacer nada de eso - aunque se interesara en los rumores y creyera en las mentiras-, para el teatro no se trata de asentar una verdad; el objetivo pudiera ser convertir la peste en un acontecimiento que deje ver el desorden, los cataclismos y las luchas.

El ébola, ese mensajero trasatlántico, viene de los países centroamericanos a los que la población negra llegó deportada del África para trabajar en las plantaciones, a falta de suficiente mano de obra indígena, también esclava (ver Leiva Vivas, Tráfico de esclavos). ¿No podría leerse esta llegada inesperada y temida como un regreso de hechos pasados, de antiguos desórdenes que aún no se han resuelto, de conflictos vivos aunque opacos, de viejas luchas que subsisten? El teatro podría saltar las cadenas de evidencias que sostendrían una interpretación etnográfica, lanzándolas al aire como una nueva cartografía de las desgracias y los humores, de las pestes que son como momias en sarcófagos históricos y biológicos, que vuelven a levantarse de sus tumbas y salen a recorrer el mundo del que fueron apartadas. Como si África regresara a las rutas esclavistas repartiendo la enfermedad y la muerte; un África fantasmal, saturada de conflictos y luchas, que horada los cuerpos y une lo que parecía distante, que viene a cobrar sus deudas en estos territorios de haciendas y plantaciones, de esclavos y amos.

Tenosique está cerca de todo eso, pero parece darle la espalda y desconocerlo. Sirvió de puerto para las exploraciones de la Selva Lacandona, abasteció las monteras que utilizaban mano de obra indígena semi-esclava y endeudada (ver De Vos, Oro verde). Los troncos de los bosques centenarios de caobas y otras maderas preciosas bajaron por el Usumacinta hasta Tenosique, donde fueron contados y clasificados y luego siguieron su curso hasta la desembocadura del río, para ser llevados a los puertos de Europa y Estados Unidos. En esas bodegas se fueron miles de árboles y miles de vidas: los frutos abundantes de la tierra y la corta vida de la gente. Viejos lazos se crearon - cuyos rastros podríamos 
seguir - entre la densa oscuridad de la selva y esos puertos industriales, ciudades del capitalismo triunfante e imperial que explotaba las lejanías para producir los nuevos bienes que se creaban en las metrópolis.

Es desde esas lejanías - el África esclava- que arriba el ébola, la peste, recordando que el desorden permanece, que las plantaciones han sido cosechadas por esclavos y que también los árboles fueron serrados por esclavos. La memoria de la esclavitud no se disuelve: en el cuerpo de un migrante muerto, mensajero de epidemias, regresan de pronto los viejos conflictos, las luchas seculares.

¿No es todo esto lo que habría que descargar con la fuerza de una epidemia sobre los espectadores, para que fueran contagiados de esas luchas y esos conflictos que siguen vigentes y, en muchos sentidos, continúan siendo propios? El teatro, se lamenta San Agustín, produce en un pueblo "las más misteriosas alteraciones" (Artaud, El teatro 29). "Ante todo - escribe el francés - importa admitir que al igual que la peste, el teatro es un delirio y es contagioso" (30).

Se podría reemplazar ébola por teatro, recuperar las herencias de los rumores y reconstruir los conflictos y las luchas. El teatro velaría el cadáver del migrante, pero no desmentiría los rumores en torno a su muerte. Los rumores son la reactivación de ese desorden que aún aflige al presente, no constituyen mentiras sino verdades trastornadas y trastocadas. Corresponde al teatro producir una nueva línea de epidemias históricas, otras cartografías para la opresión y la memoria que trasfieran, de la mano de epidemias fantasmas, las esclavitudes reales. Que traigan de regreso a los barcos desde los puertos imperiales hasta la desembocadura del Usumacinta y los árboles a las húmedas montañas de la selva; que restituyan las vidas de los esclavos y resuciten al migrante muerto en una carretera, su cuerpo reventado por el calor infernal y los largos trayectos que deben recorrer los centroamericanos para adentrarse, desde la frontera con Guatemala, en territorio mexicano, a pie y evadiendo a la policía y autoridades migratorias. La etnografía carece de métodos de resurrección; es una ciencia de muertes definitivas.

El teatro debería "resucitar a los muertos" y no sólo hacer su duelo. ¿Cómo resucitar cuerpos? Acaso podríamos resucitar sus deseos, que son los últimos rastros de vida de esos cuerpos. Resucitar los deseos para salvarlos de la muerte...

La etnografía se pregunta por el futuro inmediato de los hechos y puede revisar un espectro más o menos amplio de su pasado. Puede seguir las líneas políticas, económicas o míticas. Llega hasta donde puede establecerse cierta claridad e inteligibilidad. El teatro empieza donde no se puede decir más, en la impotencia de la palabra y la memoria, y avista estrategias de resurrección. El duelo puede ser el inicio un camino, pero no necesariamente el único ni el final. La resurrección debe tocar, finalmente, al deseo. Se debe resucitar el deseo. 
INVESTIGACIÓNTEATRAL

Revista de artes escénicas y performatividad

Vol. 9, Núm. 13

abril-septiembre 2018
Figuras del límite: Documentos, etnografía y teatro

Rodrigo Parrini

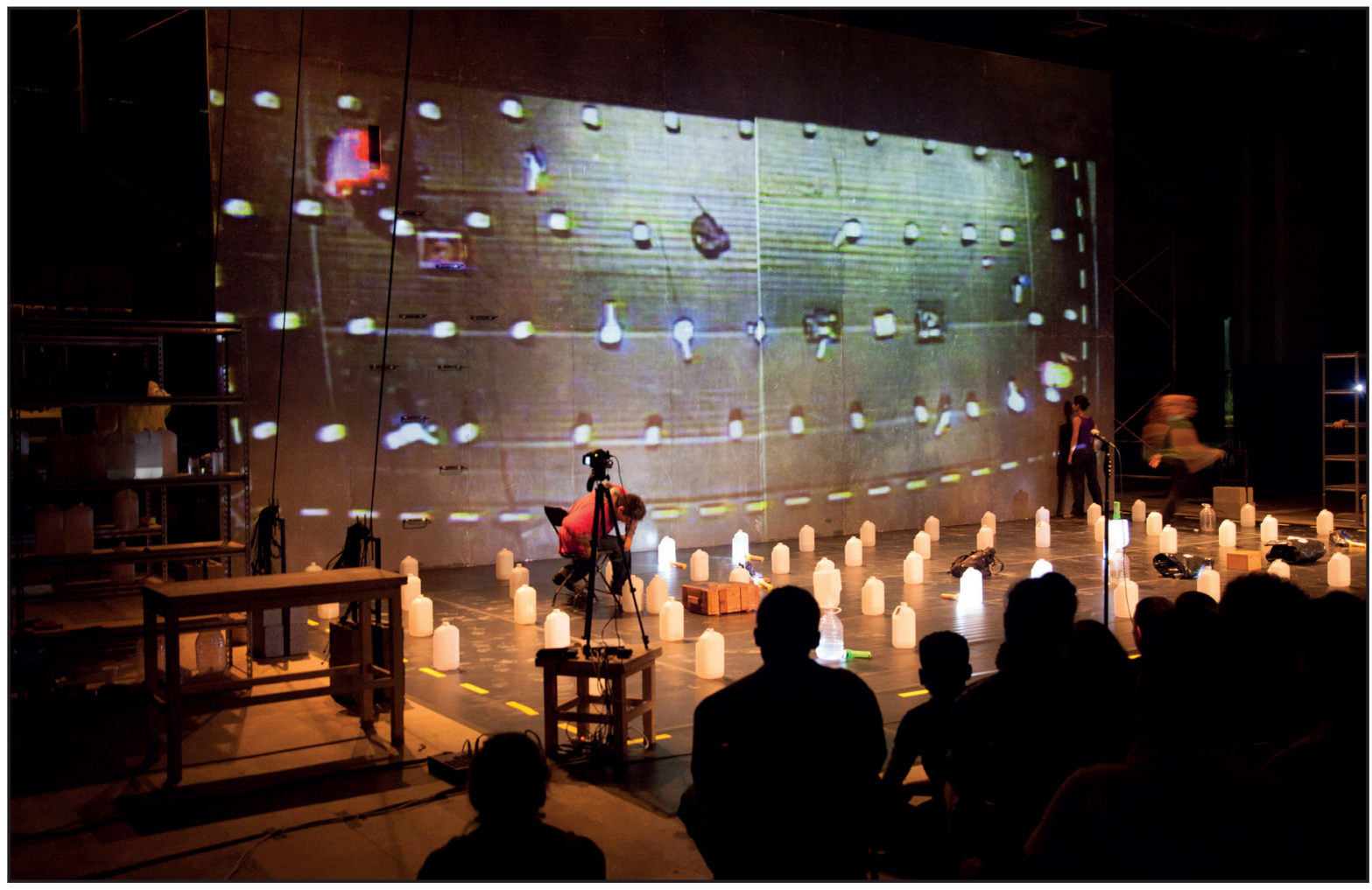

Escenografía de Amarillo. Tenosique, México, 2013. Fotografía de Marina España

\section{Segundo límite: la muerte y la soberanía}

En noviembre de 2013, Teatro Línea de Sombra montó en Tenosique su obra Amarillo, ${ }^{9}$ dedicada a la migración. Era un movimiento paradójico, porque la pieza estaba construida con relatos y materiales de la migración que atraviesa la frontera norte de México y se adentra en los desiertos de Estados Unidos. Mientras que la ficción ocurre en un lugar donde impera la arena, la puesta en escena se presentó en un lugar lleno de agua, una antigua selva tropical. La escenografía fue imponente: un muro oscuro de 12 metros de ancho y 8 metros de alto; era una transposición de la frontera norte en la frontera sur.

9 El texto explicativo que escribió la agrupación sobre la representación dice: "Un hombre ha partido y no se sabe nada de él. Amarillo, Texas, es el destino al que nunca arribó. Una mujer en la distancia reconstruye su cuerpo, su identidad, su probable itinerario y un discurso imaginado del ausente... Ese hombre y esa mujer tienen múltiples rostros, cientos de miles de identidades que conforman la imagen de un pueblo en éxodo continuo que se vacía lentamente" (TLS parr. 1). 
INVESTIGACIÓNTEATRAL

Revista de artes escénicas y performatividad

Vol. 9, Núm. 13

abril-septiembre 2018
Figuras del límite: Documentos, etnografía y teatro

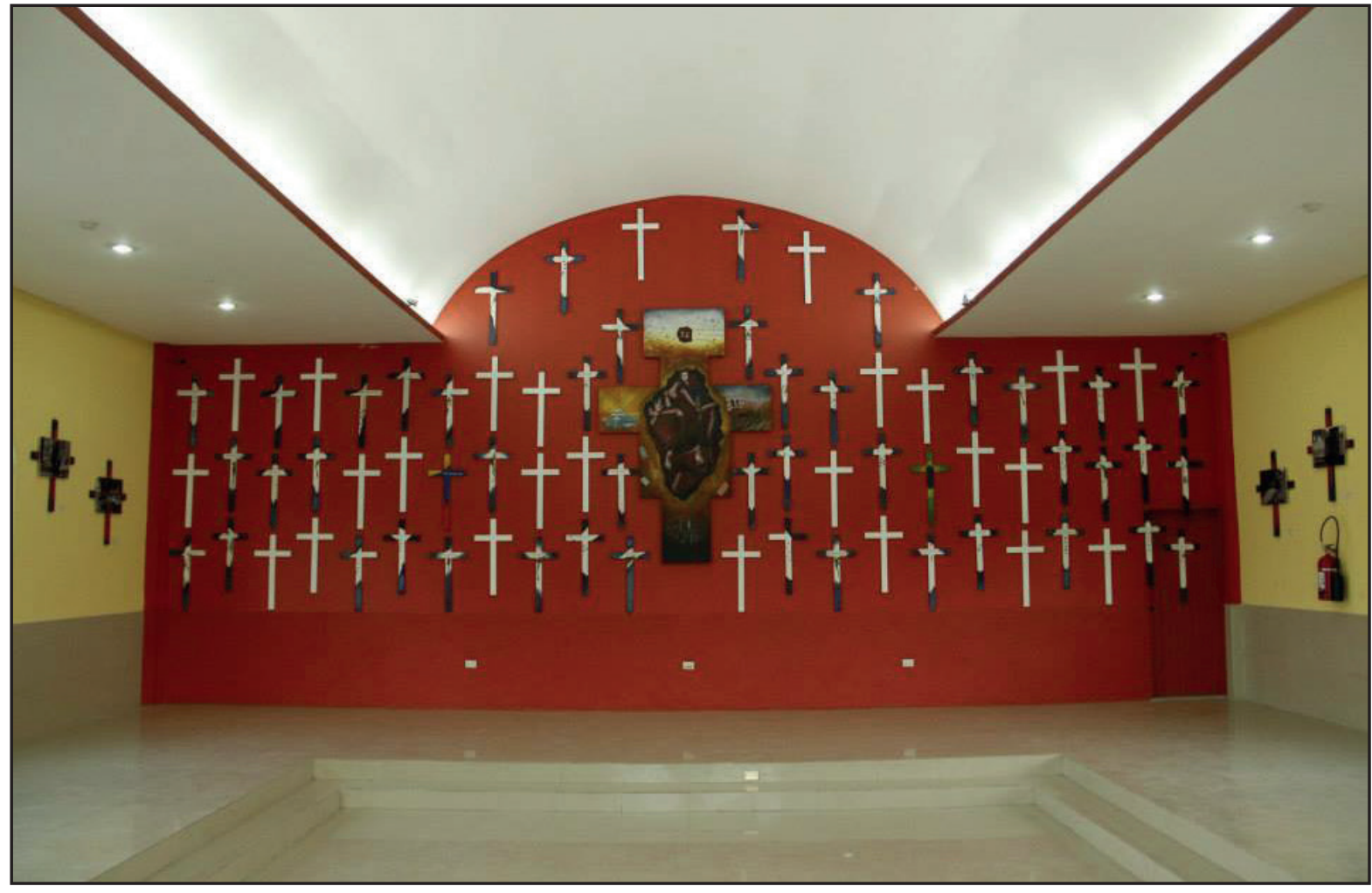

Muro norte, Capilla "La 72”. Tenosique, México, 2014. Fotografía de Rodrigo Parrini.

TLS construyó un muro en el límite y levantó una pared en la frontera, creando entonces un oráculo: el muro en 2013 era un obstáculo de la frontera norte; en 2015, ya lo era también de la frontera sur. ¿Cómo pudo el teatro adelantarse a los hechos?, ¿acaso puede funcionar como un oráculo? Creo que parte de la respuesta reside en su capacidad de mover signos y actos.

La política traza relaciones posibles, reales, entre signos y actos; por su parte, el teatro traza relaciones imaginables y en ese momento se transforma en una máquina de adivinar, no el futuro de las burocracias y las racionalidades, sino el de los actos o las vidas. TLs instaló un muro y produjo su evidencia. Lo soñó de algún modo y le otorgó una materialidad futura.

Los cuerpos figurantes del teatro anuncian los cuerpos documentados del mundo. El migrante-figural expone al migrante-in/documentado. En ese borde surge un límite. Las figuras del límite son diagramas, no individualidades; son máquinas, no identidades.

Por otra parte, en la pared norte de la capilla del Hogar-Refugio para Migrantes "La 72, hay setenta y dos cruces que recuerdan a los viajantes masacrados en San Fernando, 
Tamaulipas, en 2010. El muro es un panteón y un espacio conmemorativo: setenta y dos cruces para igual número de vidas. Dicha pared mira hacia el norte, una frontera violenta e impune donde fueron asesinados aquellos migrantes (casi todos centroamericanos). Nuevamente surge de allí un aparato predictivo, un anuncio: quien mira esas cruces también ve un destino posible. No han sido sólo setenta y dos, han sido tal vez miles los migrantes muertos en su paso por México.

Dos muros: el que levantó provisionalmente TLS y que miraba hacia el sur, aunque representaba las coordenadas espaciales y militares de la frontera norte de México, y un cementerio vertical permanente, también confrontando al norte. Dos límites y dos figuraciones, la muerte y la soberanía. El muro soberano del teatro que se levanta para impedir el paso de los migrantes y que contiene el relato de la pieza teatral; el muro mortuorio del Hogar que conmemora la muerte injusta de migrantes, anónimos en su mayoría. La soberanía es un muro vacío pero gigantesco; la muerte, una pared plagada de cruces.

Dos horizontes y dos oráculos que dicen lo mismo de formas diversas. El muro del teatro que anuncia el desierto y la sequedad; el muro de la capilla que profetiza la muerte y el crimen. Dos miradas pétreas sobre una frontera lejana que visibilizan el futuro de los cuerpos. En ese momento, los cuerpos líricos de los muros se entrelazan con los cuerpos (in)documentados de los migrantes. Las cruces son los objetos líricos de la muerte; el muro, oscuro documento de las soberanías estatales. Las cruces documentan el cuerpo lírico de los muertos y su anonimato; los muros del teatro, el espacio lírico del desierto y la persecución.

Creo que sería difícil saber dónde empieza el arte en estos deslindes, si en las cruces o en la pieza teatral, en los muros desunidos o en los relatos convergentes de ambas intervenciones. Ambos volúmenes son lenguajes, materialidades que profetizan.

Antonin Artaud escribe que "no hablamos para hacernos comprender, sino tan sólo en el interior de nosotros mismos; con un hierro de angustia, con el filo de una obstinación encarnizada, invertimos, desnivelamos el pensamiento" (El arte 106). Invertir el pensamiento es colgarlo como la figura del tarot, darle vuelta e inaugurar esa mirada de cabeza. Pero también podría implicar levantar el pensamiento como se levantan esos muros, extenderlo verticalmente para corretearlo por las alturas. Los muros son aquí inversiones, lo hemos dicho: una frontera por otra, cruces conmemorativas por muertes reales.

El muro de TLS es su propio documento: oscuro, vacío, inmóvil. En cambio, el muro de "La 72" es una especie de cuadro barroco sin espacios vacíos que sólo soporta las cruces. Muro lírico, figuras del límite, parcas oscuras o brillantes y excesivas, mortuorias o políticas.

La etnografía no levanta muros pero sí los puede documentar. Ir de uno a otro para trazar relaciones. En algún sentido, ella guarda la mirada de muros que se levantan o desaparecen, trabaja en medio de la evanescencia de los actos y de los acontecimientos para atestiguar su existencia y explicar sus razones. Etnografía mural que dibujará luego otras 
INVESTIGACIÓNTEATRAL

Revista de artes escénicas y performatividad

Vol. 9, Núm. 13

abril-septiembre 2018
Figuras del límite: Documentos, etnografía y teatro

Rodrigo Parrini

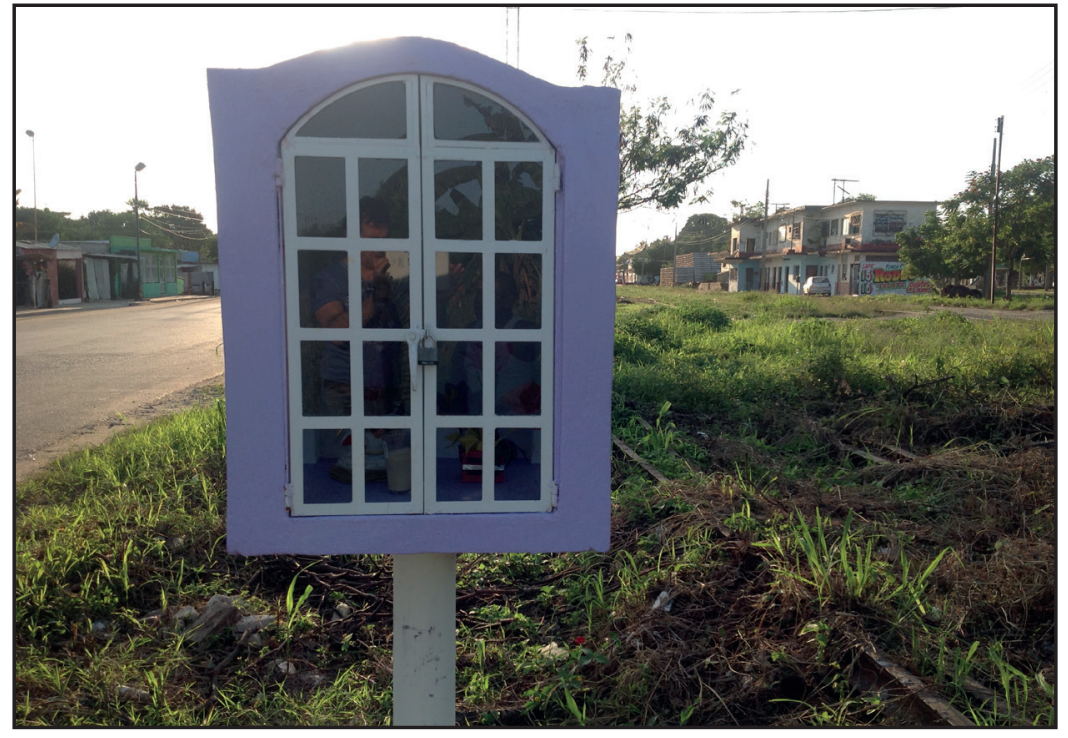

Nicho a las orillas del tren. Tenosique, México, 2014. Fotografía de Rodrigo Parrini.

coordenadas en la escritura. El muro que levantó TLS ya no está en el lugar donde fue construido. Cuando yo acababa de conocer "La 72", el muro norte de la capilla estaba vacío. Algo desapareció y también algo emergió.

Quisiera destacar los desplazamientos de los que somos testigos y que cuestionan ciertos marcos disciplinarios. El muro que levantó TLS corresponde a un deslizamiento poético de los lugares que se citan en la pieza: el muro tecno-policial que clausura la frontera norte, los migrantes muertos en el desierto de Arizona. El muro de "La 72", por su parte, desplaza las muertes que han sucedido en otra ciudad hasta un edificio en Tenosique e inmoviliza la tragedia. Uno documenta ritualmente la masacre, mientras que el otro poetiza escénicamente la muerte y la pérdida. En algún sentido, ambos son muros conmemorativos que producen un documento de lo que se ha desvanecido o no ha sido registrado. ¿Qué sucedió con ese edificio aciago en el que fueron encontrados los migrantes asesinados? Son ruinas, lugares a los que nadie regresará. En esa medida, el teatro y la etnografía se entrecruzan para documentar las ruinas y poetizarlas, para crear artefactos de memoria que sirvan, al menos, como diques para un proceso sociopolítico de eliminación de ciertos sujetos y destrucción de las huellas de la violencia.

\section{Tercer límite: el altar y la Bestia}

Cuando TLS estuvo en Tenosique, realizó una serie de intervenciones paralelas al montaje teatral. Una de ellas fue la construcción de un pequeño altar, un nicho, a las orillas del tren 
que cruza la ciudad. Unos albañiles hondureños edificaron el pequeño nicho y una vecina, que tiene un negocio a la orilla de las vías del tren, donó una imagen de la Virgen de Guadalupe. El altar se encuentra casi al lado de las vías férreas y a unos metros de la estación de trenes abandonada.

Al tren que pasa por Tenosique le llaman La Bestia. Hoy, La Bestia corresponde a la compleja red ferroviaria que cruza México de sur a norte, aunque en primer lugar fue el nombre del tren que transita específicamente entre Chiapas y Oaxaca.

Si el muro de TLS es una figura de la soberanía estatal, es posible señalar ahora a La Bestia como otra figura igualmente soberana. Podemos diferenciar, aparte, entre un muro soberano y estatal (el de la pieza teatral), frente a otro sagrado y religioso (el de "La 72", conmemorativo de las masacres de migrantes que han sucedido en México). Se trata de la misma superposición que ocurre paralelamente entre el altar con una Virgen a las orillas del tren, bordeando el paso de La Bestia.

No puedo explicar esos entrecruzamientos, pero, a mi entender, está en juego un proceso histórico de largo alcance que produce enigmas como los que acabo de mencionar. ${ }^{10}$ Agamben definirá a la nuda vida como una "zona de indiferencia y de tránsito permanente entre el hombre y la bestia, la naturaleza y la cultura" (Homo Sacer I 141). Las figuras del límite que hemos explorado son todas figuras de la nuda vida: zonas de indiferencia y tránsito entre lo humano y la bestia (la peste, la muerte, la masacre). La nuda vida surge en ese entrecruzamiento de coordenadas quizás inesperadas y diversas. La peste y el teatro, el teatro y la muerte, los muros y las masacres, los altares y los trenes... son los mapas del abandono, umbrales líricos y documentales de la violencia.

Artaud afirma que el único valor del teatro es "su relación atroz y mágica con la realidad y el peligro" (El teatro 101). Una zona indiferenciada que es posible poetizar sin eludirla: la realidad y el peligro es documentada por la etnografía, mientras que el teatro tiene posibilidades de imaginarla y conmoverla. Por eso la relación de este último con la realidad es atroz y mágica, como escribe el francés, mientras que para la etnografía sólo puede ser atroz porque la magia no le está permitida, salvo como objeto de estudio. El etnógrafo no puede operar mágicamente - esto es, líricamente- sobre la realidad para producirla de otro modo; puede documentar el peligro pero no abordarlo con la imaginación. Si la etnografía fuera el documento, el teatro sería la lírica, retomando la distinción de Didi-Huberman. El problema que me concierne es que nada de lo que aquí investigo es completamente documental o totalmente lírico; esos espacios y fenómenos son más bien híbridos.

10 Profundizo estos análisis en Parrini, Deseografías. 
INVESTIGACIÓNTEATRAL

Revista de artes escénicas y performatividad

Vol. 9, Núm. 13

abril-septiembre 2018
Figuras del límite: Documentos, etnografía y teatro

Rodrigo Parrini

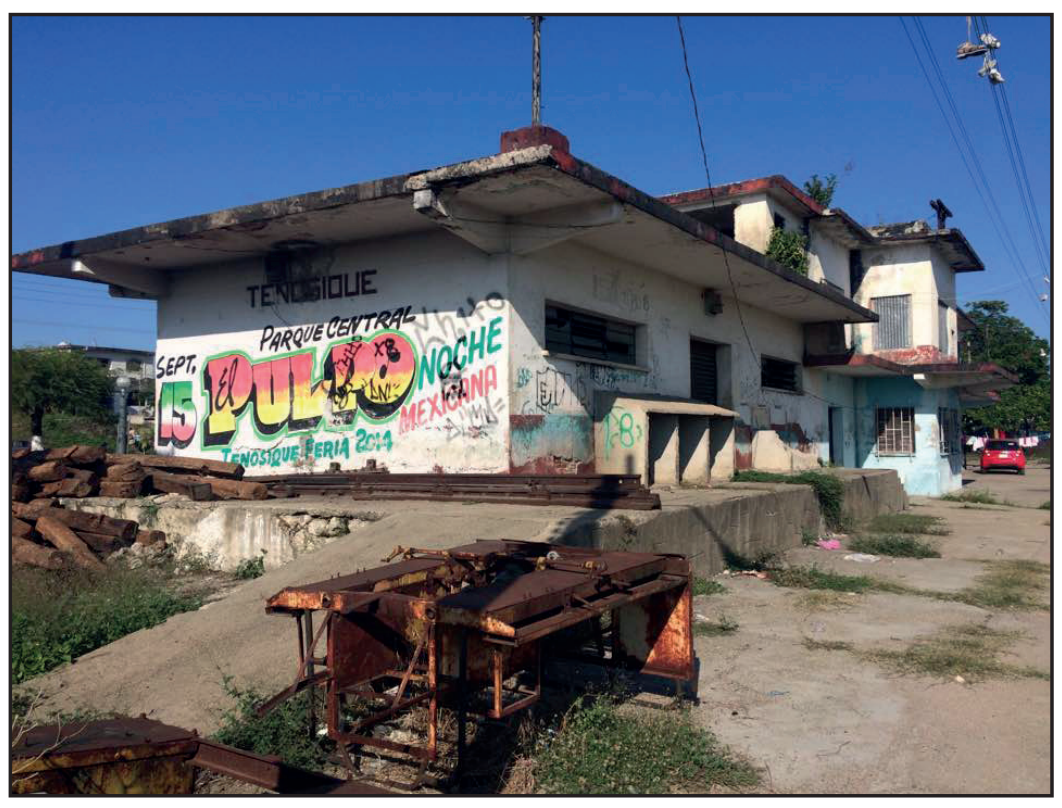

Estación de trenes.

Tenosique, México, 2014.

Fotografía de Rodrigo Parrini.

Me acerqué al teatro porque había encontrado un límite en mi propio trabajo de investigación: registrar las líricas cotidianas mediante procedimientos documentales. Si bien eso era posible en cierta medida, el elemento más intenso de esas líricas se perdía; por ejemplo, el momento más deslumbrante de las figuras del límite: cuando La Bestia pasaba a 50 kilómetros por hora, enorme y ruidosa, intensa y metálica, a la orilla de la imagen de una Virgen pequeña y discreta alojada en un nicho. En ese instante surge la figura del límite, pero no se puede registrar etnográficamente. Puedo dar cuenta de los hechos como lo hago aquí, pero no de su poder estético, de su profundidad histórica, de su urgencia política. Las bestias y las vírgenes necesitan de otros lenguajes. La nuda vida debe ser rodeada de otras imágenes, de líricas que la vistan, como se visten las vírgenes o se cubren los muros de recuerdos, de anuncios o verdades.

El nombre que se le puso al tren, ¿no es un modo lírico de dar cuenta de un problema político? La intervención de TLS al colocar ese nicho con su Virgen, buscaba producir otras liminaridades en el espacio indefinido de las líneas del tren; un terreno deshabitado y hostil que divide a la ciudad. La imagen de la Virgen, no obstante, produce otras líneas: verticales, dadas las topologías divinas del catolicismo; pero también radiales, porque hay otras imágenes cerca de ella: la vecina que donó la pequeña figura vive a una orilla, "La 72" está a menos de 300 metros del lugar... Las vías del tren atraviesan la ciudad de norte a sur y el tren se desliza por ellas. La Virgen traza líneas verticales de conexión divina desde la quietud del nicho. La antigua estación de trenes está deshabitada y derruida; la Virgen habita una 
pequeña habitación transparente. A veces, a las orillas de las vías del tren duermen algunos migrantes. Los recintos del estado en ruinas; una imagen religiosa alojada en un cuarto de cristal y concreto; los migrantes a la intemperie. La intervención de TLS abre una serie de interrogantes sobre las habitabilidades y la durabilidad de los lugares y las experiencias. Es llamativo que lo más efímero, pero también precario, esté del lado de los migrantes. La Virgen ¿no es también una estrategia lírica para confrontar la vulnerabilidad estructural de esos sujetos? La etnografía puede documentar esas intervenciones, las relaciones complejas en las que se insertan, pero también las densidades simbólicas y espaciales que producen. Un documento sobre la producción lírica del mundo.

Cuando Fray Tomás González, director de "La 72", inauguró y bendijo el nicho construido por TLS, dijo que el lugar donde estaba emplazado era un "territorio del mal", porque ahí secuestraban a los migrantes y en casas vecinas funcionaban redes de tratas de personas, que participaban de la explotación criminal de ese sector. Sus palabras, lacerantes y sonoras, se esparcieron entre los asistentes y la hierba que crece en esos terrenos. La Virgen había sido bautizada por el clamor político de un fraile que denunciaba la injusticia, cercana a todos los que participábamos en la bendición. Él hablaba en nombre de Dios y, en esa medida, podía interpelar directamente a La Bestia que cruzaba esos parajes, reeditando viejas escenas de la soberanía estatal. En alguna medida, ese pequeño recinto no documentaba la fe de los migrantes sino la brutalidad de su experiencia. El director de "La 72" desplegaba una retórica de la denuncia que articulaba, en torno a La Bestia -esa figura poética de las máquinas y las mercancías, de la violencia y los desplazamientos-, la relación enormemente compleja entre los aparatos del estado, los deseos de las multitudes (migrantes) y las formas micropolíticas de solidaridad y amparo que servían como refugio y contrapeso ante la violencia y el abandono.

No sabría decir si ese excedente discursivo y estético que produjo la intervención fue recopilado por TLS e integrado a sus dramaturgias y estrategias artísticas. Me parece que el teatro, comparado con la etnografía, cuenta con pocas estrategias de documentación. Tampoco se percibía un interés en registrar todo eso, como si lo que el arte producía no consiguiera integrarse al arte mismo y se deslizara hacia el olvido o la insignificancia.

Seguí durante varios años el destino de ese nicho. Alguna vez prendieron velas, lo que indicaba que tal vez se estaba transformando en un lugar de culto. Luego se comenzó a deteriorar. La vecina que había regalado la Virgen la rescató y la puso en su casa. En algún momento de 2016, tiraron la pequeña construcción y el nicho desapareció por completo. Estos hechos, las ruinas que produce una intervención artística, sólo interesan a la etnografía. El destino del nicho no inquietaba a TLS, aunque no era sólo su suerte lo que estaba en juego; también se trataba del destino del arte. Donde termina el teatro, empieza la etnografía. 
Al conceptualizar lo que denomina un "arte relacional", Nicolas Bourriaud escribe que:

La posibilidad de un arte relacional -un arte que tomaría como horizonte teórico la esfera de las interacciones humanas y su contexto social, más que la afirmación de un espacio simbólico autónomo y privado- da cuenta de un cambio radical de los objetivos estéticos, culturales y políticos puestos en juego por el arte moderno (Estética relacional 13).

La intervención de TLS se localizaba en ese campo. ${ }^{11} \mathrm{Si}$ fuera cierto que el arte puede tomar en cuenta "la esfera de las relaciones humanas y su contexto social", tendría que considerar sus efectos. ¿Qué sucede con esos horizontes relacionales que rompen con la inscripción mercantil del arte, pero que también abren otras interrogantes sobre sus propuestas políticas? Bourriaud se pregunta: “QQué es una forma cuando está sumergida en la dimensión del diálogo? ¿Qué es una forma que sería relacional en su esencia?” (Estética relacional 21). ¿El nicho es una forma? La imagen de la Virgen, ¿no es un "rostro que nos mira", en palabras de Serge Daney?; ¿cuáles son las relaciones que inauguran?, ¿qué diálogos?

\section{Lo posible y lo imaginable}

$\mathrm{El}$ arte, escribe Bourriaud en otro texto, obtiene su fuerza "circulando libremente en el universo del producto y del desperdicio, constituyendo a la vez un resto y un valor" (Bourriaud, La exforma 140). Para mí, ese circuito de lo intercambiable y lo inservible, lo valioso y lo desechable, lo entero y lo fragmentado, también es el campo de una antropología que trabaja en espacios y con sujetos liminares. La he llamado, en otra parte (Parrini, Falotopías), una antrapología: una práctica etnográfica materialista que se hace cargo de recolectar desechos de distinto tipo y reflexionar colectivamente sobre ellos. El etnógrafo es un pepenador (hermoso término náhuatl que significa recoger) no en tanto guarda cosas, sino porque trabaja entre desechos y desperdicios, con los colectivos desplazados y residuales. Una antrapología participaría de lo que Bourriaud denomina "un

${ }^{11}$ La intervención fue diseñada e implementada por el artista visual Alfadir Luna, que formó parte del Seminario de Medios Múltiples dirigido por José Miguel González Casanova; una de las instancias que ha promovido el arte relacional en México. Su principal trabajo se desarrolla en los mercados públicos de la Ciudad de México, en los que interviene ciertos diálogos y procesos de gestión colectiva para propiciar un ritual sui generis que vincula distintos mercados del Centro Histórico de la ciudad. 
ámbito de lo exformal: el lugar donde se desarrollan las negociaciones fronterizas entre lo excluido y lo admitido, entre el producto y el residuo" (11). Ese ámbito se interesa por todo signo "transitando entre el centro y la periferia, flotando entre la disidencia y el poder" (ibid).

En ese interregno se localizaron las intervenciones de TLS y también la reflexión que he elaborado en este artículo. Para el arte contemporáneo, la distinción entre un trabajo documental y otro lírico está caduca. No así para la etnografía, aunque el documento no sea un dato objetivo ni lo lírico una creación inspirada. Un documento - por ejemplo, el nicho des(h)echo a la orilla del tren - también guarda un potencial lírico que forma parte de su propio carácter documental. No es posterior a él ni añadido. La Virgen de las orillas era un documento visual y poético. Pero la etnografía es una disciplina de las oscilaciones, de modo que puede documentar el momento o el modo en que una propuesta lírica (nicho, obra, fotos) se transforma en un documento.

En ese sentido, esta práctica de investigación se mueve entre lo posible y lo imaginable. No es una disciplina de los hechos solamente, sino también de las ficciones que dan forma a un mundo. En esa medida, el teatro surge como un aliado conflictivo que le permite potenciar lo imaginable y cuestionar lo posible. Si el documento fuera un registro de lo posible, lo lírico sería otro de lo imaginable.

\section{Bibliografía}

Agamben, Giorgio. Homo sacer I. El poder soberano y la nuda vida. Trad. Antonio Gimeno. Valencia: Pre-Textos, 2006.

Artaud, Antonin. El arte y la muerte / Otros escritos. Trad. Víctor Goldstein. Buenos Aires: Caja Negra, 2005.

Artaud, Antonin. El teatro y su doble. Trad. Enrique Alonso y Francisco Abelenda. Madrid: Edhasa, 2001.

Bourriaud, Nicolas. La exforma. Trad. Eduardo Berti. Buenos Aires: Adriana Hidalgo, 2015.

Bourriaud, Nicolas. Estética relacional. Trad. Cecilia Beceyro y Sergio Delgado. Buenos Aires: Adriana Hidalgo, 2013.

Descola, Philippe. "On anthropological knowledge”. Social Anthropology, vol. 13, núm. 1, 2005, pp. 65-73.

De Vos, Jan. Oro verde. La conquista de la Selva Lacandona por lo madereros tabasqueños, 1822-1949. México: Fondo de Cultura Económica, 1996.

Didi-Huberman, George. Pueblos expuestos, pueblos figurantes. Trad. Horacio Pons. Buenos Aires: Manantial, 2014. 
Fábregas Puig, Andrés. "El concepto de frontera: una formulación". Fronteras des-bordadas. Ensayos sobre la frontera sur de México. Coord. Alain Basail Rodríguez, México: Ediciones Casa Juan Pablo, 2005, pp. 21-52.

Haraway, Donna. Testigo_Modesto@Segundo_Milenio.HombreHembra@_Conoce_Oncoratón ${ }^{\circ}$. Feminismo y tecnociencia. Trad. Helena Torre. Barcelona: Universidad Oberta de Catalunya, 2004.

Ingold, Tim. "Anthropology is Not Etnography". Proceedings of the British Academy, vol. 154, 2008, pp. 69-92.

Jodorowsky, Alejandro. Psicomagia. Madrid: Siruela, 2004.

Jodorowsky, Alejandro y Marianne Costa. La vía del Tarot. Trad. Anne Hélène Suárez. México: Grijalbo, 2004.

Leiva Vivas, Rafael. Tráfico de esclavos negros a Honduras. Tegucigalpa: Secretaría de Cultura, Artes y Deportes, 1982.

Nader, Laura. "Ethnography as theory". HAU: Journal of Ethnographic Theory vol. 1, núm. 1, 2011, pp. 211-219.

Parrini, Rodrigo. "Canto de palomas. Teatro de animales y etnografía del espacio”. Cartografías Críticas. Comp. Ileana Diéguez, vol. II. Los Ángeles: Ediciones Karpa, en prensa.

Parrini, Rodrigo. "Cuerpos figurantes, cuerpos incircunscritos. Un carnaval migrante en la frontera sur de México". Lo complejo y lo transparente. Investigaciones transdisciplinarias en ciencias sociales. Comps. Eva Alcántara, Yissel Arce y Rodrigo Parrini, México: Universidad Autónoma Metropolitana, Xochimilco, pp. 69-98, 2018.

Parrini, Rodrigo. Deseografías. Una antropología del deseo. México: Universidad Autónoma Metropolitana, Xochimilco, Centro de Investigaciones y Estudios de Género, UNAM, 2018.

Parrini, Rodrigo. Falotopías. Indagaciones sobre la crueldad y el deseo. Bogotá y México: Instituto de Estudios Sociales Contemporáneos, Universidad Central y Centro de Investigaciones y Estudios de Género, UNAM, 2016.

Saskia Sassen. Expulsados. Brutalidad y complejidad en la economía global. Madrid: Katz, 2015.

Teatro Línea de Sombra. 2017. Teatro Línea de Sombra, en línea. Consultado el 19 de agosto de 2017.

Turner, Victor. The Ritual Process. Structure and Anti-Structure. Ithaca: Cornell University Press, 1991. 